\title{
Reinforcing Civics Literacy in Sustaining Students' Learning in the Industrial Era 4.0
}

\author{
Riska Anggraini Saputri*, Muchtarom, Triyanto, Winarno
}

Universitas Sebelas Maret of Surakarta, Indonesia

Received July 9, 2019; Revised September 9, 2019; Accepted September 16, 2019

Copyright $\bigcirc 2019$ by authors, all rights reserved. Authors agree that this article remains permanently open access under the terms of the Creative Commons Attribution License 4.0 International License

\begin{abstract}
This research aims at determining the strategic reinforcements of Civics literacy in sustaining the learning in the 4.0 industrial era. The 4.0 education is a response to the needs of the 4.0 industrial revolution where humans and technology are mutually sustaining the educational advancements. This research was designed with qualitative research methods using purposive sampling technique. The subjects were the teachers of Civics Education subject and students of Junior High School. The data were collected by using the techniques of document study, interviews, and observation. Those data analysis techniques were conducted following the data reduction, data presentation, drawing conclusions, and verification. This research explored the 4.0 education trend that concerns with its several learning strategies of HOTS (higher thinking order skills), 4C (critical thinking, collaboration, communication, and creativity), reinforcing character education, and literacy. Civics literacy reinforcement has been a demand along with the development and the information technological advancements progress in fostering the critical citizens. The results indicated that the Civics literacy reinforcement in sustaining the learning in the 4.0 industrial era were carried out using several strategies, among others; 1) Civics knowledge through the development of digital literacy-based Civics education material; 2) Civics skills through the HOTS and 4C learning process; 3) Civics dispositions through character education reinforcing programs.
\end{abstract}

Keywords Reinforcing, Civics Literacy, Civics Education, the 4.0 Industrial Era

\section{Introduction}

The issue of literacy has been an important concern in Indonesian education, where the level of literacy in this country remains at low and has not been internalized in people's everyday social lives. Literacy is an important means of communication which allows individuals, communities, and institutions to interact from time to time and throughout space by using language in a network of social relations (Benavot, 2015). Literacy, especially critical Civics literacy, is basically an innate skill, the ability to be acquired through teaching or acquisition. Having literacy implies that individuals have expertise in social and political knowledge, understanding, attitudes, and skills (Teitelbaum, 2010).

The results of the study carried out by the Program for International Student Assessment (PISA) in 2015 noted that Indonesia was ranked 62nd with a score of 397 out of a total of 70 state participants in the literacy category. Furthermore, Indonesia's literacy rate data in 2016 according to Central Connecticut State University, Indonesia is ranked 60th out of a total of 61 countries.

The low level of literacy shows that education has not been able to develop students' competencies and interests in knowledge. Meanwhile, the use of information technology in education plays a significant role in obtaining information quickly and widely, increasing cooperation and communication with others, and fostering personal habits of active learning and lifelong learning ( $\mathrm{Xu}$, 2016).

The low levels of literacy have a major impact on the quality of education in Indonesia. This happens due to the increase in internet users which has not been equally balanced with the increase in digital literacy. Digital literacy is aimed at increasing individual's ability to read, analyze, and use information in the digital world (big data). Technology literacy aims to provide an understanding of the workings of machinery and technology application (Aoun J. , 2017). In the 21st century, there has been a significant change in the field of education marked by a shift in the education paradigm that should be relevant with the prepared skills of human resource competencies to deal with the industrial era 4.0. 
In the future, the number of internet users will continue to increase as evidenced by the production of mobile devices that exceed 2 billion and is estimated to reach 2.7 billion (Hanchman, 2011). Having skills in dealing with the era of advancements in communication technology, including computers and cellular devices is a fundamental ability that any learner needs to have. Digital literacy skills help students in carrying out learning activities in schools, in addition to improving human life and advancing education.

The industrial era 4.0 was marked by an increase in manufacturing digitalization followed by four driving factors such as; 1 ) the increase on data volume, computing power, and connectivity; 2) sophistication of analysis, ability, and business intelligence; 3 ) new interactions that integrate humans with machines; and 4) advanced digital transfer instructions to the physical world, such as robotics and 3D printi (Lee, Lapira, Behrad, \& Hung-an, 2013). On the other hand, education 4.0 is a response to the needs of the industrial revolution 4.0 where humans and technology synergistically facilitate education. Furthermore, Aziz Hussin (2018) suggested a new vision of learning to encourage students to learn not only the needed skills and knowledge but also identify the sustaining resources of these skills and knowledge.

In addition, Civics education is a fundamental subject and contributes to strengthening Civics literacy as emphasized by Milner (2002) "... the most likely method of improving the levels of Civics literacy is Civics education". Then Leahey (2011) suggests that, through Civics literacy, it enables students to become active participants in building their own knowledge and worldview, seeing education as a provision to face the forces that shape and limit their lives. Students who have developed Civics literacy skills understand how to become knowledgeable citizens, participate in initiating community change, and identify their own values while connecting them with the wider community (Argenal and Jacquez, 2015).

There are several existing core components in Civics literacy, i.e. Civics knowledge, Civics skills, and Civics dispositions which are determinant factors in the effort to realize smart and good citizens. Formally the constitutional importance of Civics literacy seeks to educate the nation's life stipulated in the fourth paragraph of the Preamble of the 1945 Constitution, and Article 31 of the State Constitution of the Republic of Indonesia, further explained in Article 2, 3, 37 of Law Number 20 of 2003. In the explanation of Article 37, it is stated that: "... Civics education aims at estabishing students to humans with a sense of nationality and love for the motherland".

This research is projected as strategies in strengthening students' Civics literacy oriented learning in the industrial era 4.0 in junior high school. Reinforcing Civics literacy is the impact of the push for information technology development and the flow of globalization. Thus, in supporting learning in the industrial era 4.0 based on digital technology and information, it is necessary to strengthen Civics literacy.

\section{Literature Review}

\subsection{Civics Literacy Reinforcement}

Literacy according to Teitelbaum (2010) is described as individual's awareness or knowledge in certain subject areas. Literacy, especially critical Civics literacy, is usually not an innate skill and should be taught and acquired. Having Civics literacy means being an expert in social and political knowledge, understanding, attitudes, and skills. Civics literacy concerns individuals' abilities to name, analyze, and act on social or political issues. Students who have developed Civics literacy skills will understand how to become knowledgeable citizens and participate in initiating social change (Argenal and Jacquez, 2015).

\subsection{Civics Education}

Civics education refers to formal and informal training provided to citizens aimed at enabling them to be able to develop knowledge, upholding positive the needed values and skills as effective contributions to engage political process and as civil society (Finkel , 2000). Civics education is a basic element of education in Indonesia aimed at fostering citizens to participate in the public life of democracy, consciously willing to use their rights besides carrying out responsibilities based on the necessary knowledge and skills (Adeyemi, 2018).

Civics education and human rights currently include world citizenship. Individuals are not only expected to be good citizens in their country, but also effective world-scale citizens (Kezban K. , 2014).

\subsection{Industrial Age 4.0}

Industry 4.0 introduces us to flexible mass production technological advancements (Kagermann, Wahlster, \& Helbig, 2013). Machines systematically operate independently or integrate with human abilities (Sung, (2017)Industry 4.0 is a sort of approach to controlling the production process that synchronizes time by integrating and adjusting production (Kohler \& Weisz, 2016).

Furthermore, Liffler \& Tschiesner (2013) note that the basic principle of industry 4.0 is the incorporation between machines, workflows, and systems, by applying intelligent networks along the chain and production process to control each other independently. Additionally, (Hermann, Pentek, \& Otto, 2016) the principle promoted by industry 4.0 is manufacturing interconnection between the ability of machines, devices, sensors, and humans to connect and communicate with each other through the Internet of 
Things (IoT) or the Internet of People (IoP).

\section{Methods}

This research was designed with qualitative research methods applying purposive sampling as a technique of obtaining data. The subject of this research involved Civics education subjects and junior high school students. Data collection was carried out through document study techniques, interviews, and observations. Data analysis techniques apply data reduction, data presentation, conclusions, and verification. Regarding this research, Civics literacy includes three components of citizenship, namely Civics knowledge, Civics skills, and Civics dispositions. Thus, the development of learning materials and the implementation of teaching and learning activities were used as materials which were then analyzed.

\subsection{Data Collection Process}

Data collection was carried out through document study technique including syllabus, learning implementation plans, and examining instruments of knowledge, skills and attitudes. The interview technique was carried out to Civics education teachers and junior high school students. The observation technique was carried out during teaching and learning activities in the classroom.

\subsection{Data Analysis}

The data analysis technique was carried out by means of data reduction, data presentation, conclusions, and verification. To analyze Civics literacy, a number of criteria were determined to determine the results of the assessment of Civics knowledge, Civics skills, and Civics dispositions. First, Civics knowledge analysis was realized through developing Civics Education based on digital literacy. Second, Civics skills analysis is realized through the learning process in an integrative manner using HOTS and 4C (critical thinking, collaboration, communication, and creativity). Third, Civics disposition analysis concerning character-oriented educational activities.

\section{Results and Findings}

In the Civics education context, the development of Civics literacy in the 21st century is focused more on maturing citizens towards a global-minded society. Identical global citizens thinking, heart, body and soul who are socially able to work and prepare intercultural relations can maintain their uniqueness, in addition to maintaining integrity in the public sphere.

Based on the results of this research, Civics education plays a significant role in shaping the younger generation to be smart and good citizens. Good citizens are reflected in three main aspects, namely Civics knowledge, Civics skills, and Civics dispositions. Civics education should help students through developing identity and attachment to the global community.

Civics education is a very influential subject to encourage Civics literacy reinforcement as in Milner (2002) 's opinion [........] the most likely method of improving the levels of Civics literacy is Civics education ". In addition, Leahey (2011) Critical Civics enables students to be active participants in building their own knowledge and worldviews and using education as a tool in interrogating and confronting the forces that shape and limit their lives.

Reinforcing elements in an education system urges the emergence of a reformist movement in response to the 4.0 industrial era, where one of them as proclaimed by the government, namely the new literacy movement aims to reinforce and even shift the old literacy movement. The new literacy movement is intended to focus on three main literacies namely, 1) digital literacy, 2) technology literacy, and 3) human literacy (Aoun, 2017). These three skills are predicted to be typical of fundamental skills and are needed in the dealing with industrial era 4.0.

The problems surrounding literacy have shown public interest in Indonesian education, where the level of literacy in Indonesia is considered still low and has not been internalized in people's daily lives. The low level of literacy shows that education has not been able to develop students' competencies and interests in knowledge. Therefore, to sustain technology-based learning and digital information in the industrial era 4.0, students' reinforcement of Civics literacy strategies are significantly needed.

Civics literacy concerns knowledge in the public sphere regarding governance and the role of citizens in various fields such as Civics knowledge, Civics skills and Civics disposition. This Civics literacy should be the duty of every young citizen as a provision in realizing citizens who are ready to face challenges in the industrial era 4.0. Based on the results of research carried out in junior high schools through the technique of interviewing Civics education teachers and junior high school students, Civics literacy is carried out referring to three strategies that lead to Civics knowledge, Civics skills and Civics disposition.

\subsection{Strategies Used to Reinforce Civics Literacy on Civics Knowledge through Developing Civics Education Based-Digital Literacy}

Civics literacy concerns digital citizenship which is the knowledge and skills in today's digital world. Digital citizenship concerns the ability to participate in online society (Mossberger, Tolbeert, \& McNeal, 2008). Given that this industrial revolution 4.0 era requires digital literacy as an effort to advance themselves in the online world, these skills will become an important capital in cross-country communication.

With regard to the industrial revolution era 4.0, 
technological advances change individuals' ways of life, work, socializing, and learning. This technology facilitates lifelong learning. However, in the fields of education and literacy, the potential of this technology has not been fully adapted in pursuing educational trends 4.0. Civics literacy and digital citizenship as the underlying themes of future learning activities are oriented towards increasing the understanding of citizens towards political and governmental processes.

The result of the research reinforcing Civics literacy is an important element in Civics education that aims to improve students' critical and creative thinking skills. Civics literacy is an important part of citizenship, thus, those who aspire to become smart and responsible citizens first master this literacy. Reinforcing Civics literacy, especially digital literacy is an absolute thing to do, thus, it enables the public to be able to recognize and organize news consumption which ultimately contributes to understanding the community about the truth and facts behind a news story and distinguishing between the false and true news.

The low level of skills and literacy in the digital era led to the use of incompetent technologies such as the irresponsible attitudes of using technology. Thus, the use of competence in using technology is more popularly known as digital literacy (McGonagle, 2011). Monroe (2004) adds that digital literacy includes basic, scientific, and technological literacy, visual and information literacy, multicultural literacy and global awareness. A good education should consider individual development where they are not only expected to be able to read and write but also to understand and communicate efficiently.

Based on the results of interviews and observations towards the students' Civics literacy reinforcement on Civics education subject learning process, it applied discussion method on a topic around the currently occuring controversial issues. At the time they were given the assignment, a Civics education teacher assigned students through internet access. On the other hand, the material taught is not only limited to textbooks, however, students were also asked to be actively engaged in seeking additional information through internet access. Through this digital literacy activity it is intended that students' insight into the subject matter become wider. Student literacy activities are carried out in the syntax of seeing, observing, reading, and listening.

In the context of citizenship, Milner (2002) notes that digital literacy skills are one of the competencies of Civics literacy. Regarding the relevance of Civics education in educating young citizens to have literacy competencies towards the era of industry 4.0, Banks (2008) further explained that citizenship education should help students develop their identity and attachment to the global community.

\subsection{Strategies Used to Reinforce Civics Literacy on Civics Skills through HOTS Learning Processes (Higher Order Thinking Skills) and 4C (Critical Thinking, Collaboration, Communication, and Creativity)}

Based on the results of research, technological advances including critical thinking skills, collaboration, communication, and creativity have become the key core in education, especially when dealing with Civics literacy. In sustaining the industrial era 4.0 according to Salpeter (2008), it identified a number of traits that citizens need to have. First, individuals should have the skills to make smart choices. Second, individuals are able to meet the demands of being able to be proficient in academics, interdisciplinary knowledge, and literacy. Third, individuals are required to be able to participate intelligently, productively and responsibly in the digital world.

On the basis of the research results conducted in learning activities, the 4C (critical thinking, collaboration, communication, and creativity) was carried out by students in the following syntaxes:

1. Problem statement: students carry out their critical thinking activities by identifying as many questions as possible regarding the material being studied beginning from the factual to hypothetical questions in developing creativity, curiosity, the ability to form questions to form critical thoughts that need to live smart and lifelong learning.

2. Data collection: students do mutual cooperation by establishing groups to discuss, gather information, present, and exchange information about the material being studied.

3. Data processing: students do mutual cooperation and seek critical thinking by discussing the process of observing data in groups.

4. Verification: students do critical thinking by discussing the results of their observations and verifying the data obtained or the theory used in the textbook.

5. Generalization: students engage in communication to convey the results of group discussions through a presentation session. In addition to that, students were asked to think creatively by concluding important points addressed in the previously done learning activities.

In the era of industrial revolution 4.0, it has been proven that technology is one of the important factors in everyday human life. This implies a significant impact in the world of education, especially Civics education. According to Farisi (2016), important skills of the 21st century should be internalized into the education system, including "learning and innovation skills" (including critical thinking and problem solving, creativity and innovation, communication, and collaboration). 
Meanwhile, the skills that students should have in dealing with technology-based education in the industrial era 4.0 according to Monroe (2004) include:

1. Communication, both in class and at home with parents;

2. Creativity, which allows students to create and reflect on their own understanding of the material being read or studied;

3. Critical thinking, both that occurs before and after reading activities such as asking and predicting;

4. Collaboration, which involves students reading in teams and analyzing what they read.

Applying the 4C (critical thinking, collaboration, communication, and creativity) as the basis of learning methods refers to Vygotsky's Zone of Proximal Development (ZPD) in constructivism learning theory. Vygotsky (1978) defined the "Zone of Proximal Development (ZPD) as a distance between the developmental levels of students when solving problems individually and when problem solving with others (peers, teachers, parents, etc)". Interactions occurring between students and adults or peers can encourage students' cognitive development.

Vygotsky further suggested that in the Zone of Proximal Development (ZPD), a teacher and students in mutual cooperation solve problems in a task where a student might not be able to complete individually. This interaction between teacher and student produces cognitive changes that are internalized in students. Students elaborate on their individual understanding of social interactions and construct meanings through combining these understandings with their personal experiences.

Students are able to learn concepts perfectly well if they are in ZPD. Students work in ZPD if they cannot solve problems individually, but are able to solve them after getting help from an adult or friend (peer). Given the assistance is intended so that later the students are able to do tasks or questions that have a higher level of complexity than students' level of cognitive development. This is where the importance of implementing 4C (critical thinking, collaboration, communication, and creativity) lies.

Constructivists in their perspective view the role of collaboration as great, and it is reasonable that interacting with others can stimulate the restructuring of people's understanding. The role of collaboration is growing rapidly in social constructivism (Vygotsky, 1978) stating that learning occurs first in the inter-psychological (social) realm before being internalized in the intra-psychological realm.

The reinforcing strategies of Civics literacy on Civics skills through the HOTS learning process (higher order thinking skills) significantly help students improve their critical thinking skills. 21st century oriented skill learning offers HOTS and contextual learning. This is in line with the four pillars of education according to UNESCO, namely learning to know, learning to do, learning to live together and learning to be that allow students to be able to connect learning material with their real lives.

Kenney (2013) suggested that in choosing the best option, individuals need to know how to think critically. In addition, Ennis (2011) defined critical thinking as reasonable and reflective thinking that focuses on deciding what to believe or do. For Facione (2013) critical thinking has six components, namely:

1. Interpretation, to understand the experience, data, events, assessments, rules, etc. (Ennis, 2011)

2. Analysis, to identify the relationship between events, concepts, and other forms of assessment (Demir, 2006)

3. Inference, in the sense of drawing conclusions according to available evidence (Demir, 2006)

4. Explanation, which justifies explanation in a coherent, methodical, reasonable way (Lowy, 2013)

5. Evaluation defined by Facione (2013) as the ability to assess the logical strength of actual inferential relationships or what is meant between statements, descriptions, questions, situations, etc.

6. Self-regulation, more specifically self-awareness to monitor individuals' cognitive activities (Facione, 2013).

Hagop (2015) further added that critical thinking has a fundamental role in education, namely as a means to foster democracy, related to the idea of fostering responsibility in the use and application of science, technology or scientific development. Critical thinking is seen as one of the highest sequences of cognitive abilities. (Helena Pedrosa, Aurora, \& Betina, 2014).

Rui, Celina, \& Isabel (2011) explained in his research that in various countries, many efforts have been made in integrating critical thinking into the curriculum, this is oriented, therefore, in the future living in a pluralistic society, students are able to apply their citizenship competencies. This also confirms that critical thinking is an important aspect of promoting the realization of democracy, given that critical thinking is a very important component in the contemporary education system.

Rubenfeld \& Sceffer (2015) suggested that in the modern world, being able to solve problems through critical thinking is vital knowledge that enables individuals to survive. That is in accordance with the results of research where students tested their quality by applying HOTS learning (higher order thinking skills) oriented as a Civics literacy enhancement program.

As a result of this industrial revolution 4.0, a citizen should have at least eight abilities of modern humans in the 21st century, among others, to: 1) recognize global problems, 2) cooperate, 3) tolerate, 4) critical thinking, 5) show sensitivity to human rights problems, 6) solve complex problems, 7) master technology and information, and 8) participate on the political process. 


\subsection{Reinforcing Civics Literacy Strategies on Civics Disposition through Reinforcing Character Education Programs}

Education is a central home for those who are prepared to have excellent human character. This research was conducted through a reinforcing program for character of junior high school students. Character education at least meets the needs of early adolescents (seventh, eighth, and ninth grades) to reinforce their social competence (Cheung, 2010). Some studies explored the significant contributions of character education to the social competencies of elementary school students (Miller, Kraus, \& Veltkamp, 2005). However, a contribution remains empirical evidence and generalization, given that previous research seems to have not been rigorously carried out and focused on research problems like this (Was, Woltz, \& Drew, 2006). Character education technically refers to formal lessons given to students in schools which have been internalized and in accordance with the given curriculum to reinforce students' personal characters.

Thus, character education emphasizes the development of students' overall moral character, which reaches beyond cognitive development in moral reasoning. Character education respects students' emotional and values development within a morally and socially competent manner. Weisz, Sandler, \& Durlak (2005) added that a reinforcing character education program contributed more to students who were previously with lower social competence

Individually, characters are human parts that signify one another, besides being born from birth. The innate character is not different from the character of the nation, and the national character is forged in individuals rather than innate (Koellhoffer, 2009). Character determines one's sika, thoughts and actions in their interactions with others around them. Thus, the character includes moral values, attitudes, and behaviors that manifest into everyday human habits. An individual is deemed to have a good character if they consider themselves moral, have moral feelings, and take moral actions.

Civics literacy is defined as the knowledge capacity and ability of citizens to understand their political world. In addition, it is broadly defined as the capacity of knowledge about how to actively participate in initiating community change, as well as the willingness and ability to engage in public discourses. The results of the research show that through citizenship education, it can develop the national character such as nationalism, discipline, self-confidence, honest behavior, toughness in dealing with problems of responsibility, curiosity and environmental care.

The fundamental elements determine the character of the nation should be inculcated or developed in students as the younger generation, considering they are agents of national change. Therefore, the strength of character education is very significantly given to junior high school students. Some underlying values need to be the focus of character education, including 1) reinforce the integrated aspects between knowledge with logic and honesty, 2) foster a sense of nationalism, 3) foster tolerance, 4) foster democratic values, 5) enforce the law.

\section{Conclusions}

This article concludes that Civics literacy concerns the knowledge of governance and the roles of citizens in it are divided into several sub-categories such as; Civics knowledge, Civics skills and Civics disposition. This Civics literacy is a fundamental understanding which is inevitably the obligation of every citizen, especially the young generation, as a provision to create citizens who are ready to face challenges in the industrial era 4.0. First, the Civics literacy reinforcement of the Civics knowledge is realized through developing digital literacy-based Civics education material. Strengthening Civics literacy, especially digital literacy is a fundamental thing that needs to be done so that people are able to recognize and understand the truth behind dissemination of messages from the media. Thus they will be able to determine whether the information they consume are facts and truth or even hoaxes. Civics literacy and digital citizenship are both concerned with the level of citizens 'literacy skills, where their noble and positive goals enhance citizens' understanding of the political and governmental processes. Second, the Civics literacy reinforcement strategy on Civics skills is applied through the HOTS learning process (higher order thinking skills) and 4C (critical thinking, collaboration, communication, and creativity). 4C activities were carried out by students in the syntax as follows: statement problems, data collection, data processing, verification, generalization. Third, the strategies used to reinforce Civics literacy on Civics disposition are realized through character education inculcating program. Some of the significant values concerning character education among others are: 1) reinforce the integrated aspects between knowledge with logic and honesty, 2) foster a sense of nationalism, 3) increase tolerance, 4) enchance democratic values, 5) uphold the law.

\section{REFERENCES}

[1] Adeyemi, B. (2018). Content Analysis of Civic Education Curriculum in Senior Secondary Schools in Osun State, Nigeria. Educational Research and Reviews, v13 n12 p464-471.

[2] Adeyemi, B. (2018). Content Analysis of Civic Education Curriculum in Senior Secondary Schools in Osun State, Nigeria. Educational Research and Reviews, 464-471.

[3] Aoun, J. (2017). Robot-proof: higher education in the age of 
artificial intelligence. US: MIT Press.

[4] Aoun, J. (2017). Robot-proof: higher education in the age of artificial intelligence. US: MIT Press.

[5] Aziz Hussin, A. (2018). Education 4.0 Made Simple: Ideas For Teaching. International Journal of Education \& Literacy Studies, 6, 92-98.

[6] Beanvot, A. (2015). Literacy in the 21st Century: Toward A Dynamic Nexus of Social Relation. International Review of Education, 61, 272-294.

[7] CHEUNG, C.-K., L.-Y. (33, 255-263). Improving social competence through character education. Evaluation and Program Planning.

[8] Cheung, e. (2010). Improving social competence through character education. Evaluation and Program Planning, 33, 255-263.

[9] Demir, M. (2006). Candidate teachers’ learning styles and teaching social science. Eurasian Journal of Educational Research (EJER), 23, 28-37.

[10] Ennis, R. (1985). A logical basis for measuring critical thinking. Educational Leadership, 4, 44-54.

[11] Ennis, R. (1985). A logical basis for measuring critical thinking, Educational Leadership, 4, 44-54.

[12] Ennis, R. (1985). A logical basis for measuring critical thinking. Educational Leadership, 4, 44-54.

[13] Facione. (2013). Critical thinking: What It is and why it counts. CA, Millbrae: Measured Reasons LLC, Hermosa Beach.

[14] Facione, A. (2013). Critical thinking: What It is and why it counts. CA, Millbrae: Measured Reasons LLC, Hermosa Beach.

[15] Farisi, M. (2016). Developing the 21st-Century Social Studies Skills through Technology Integration. Turkish Journal of Distance Education.

[16] Finkel, S. (2000). Can Tolerance be Taught Adult Civic Education and the Development of Democratic Values? Paper prepared for the conference „Rethinking Democracy in the New Millenniumee.

[17] Hagop, A. Y. (2015). A Framework for Guiding Future Citizens to Think Critically about Nature of Science and Socio scientific Issues. Canadian Journal of Science, Mathematics and Technology ducation, 15, 248-260.

[18] Hanchman, M. (2011). Mobile Internet Use to Pass PCs by 2015. Retrieved from /http://www.pcmag.com/article2/0.2 817.2392796.00.asp.

[19] Helena Pedrosa, d.-J., Aurora, M., \& Betina, L. (2014). So much more than just a list: exploring the nature of critical questioning in undergraduate sciences. Research in Science \& Technological Education, 3, 134-140.

[20] Hermann, M., Pentek, T., \& Otto, B. (2016). Design Principles for Industrie 4.0 Scenarios. . Presented at the 49th Hawaiian International Conference on Systems Science.

[21] Kagermann, H., Wahlster, W., \& Helbig, J. (2013). Recommendations for Implementing the Strategic Initiative
Industrie 4.0. Germany: Working Group.

[22] Kenney, J. (2013). Fostering critical thinking skills: Strategies for use with intermediate gifted readers. Illinois Reading Council Journal, 41, 28-40.

[23] Kezban, K. (2014). Teacher Perspectives on Civic and Human Rights Education. Education Research and Review, 9, 302-311.

[24] Kezban, K. (2014). Teacher Perspectives on Civic and Human Rights Education. Education Research and Review, 9, 302-311.

[25] Koellhoffer, T. (2009). Character Education Being Fair and Honest. . New York: Infobase Publishing.

[26] Kohler, D., \& Weisz, J. (2016). Industry 4.0: the challenges of the transforming manufacturing. Germany: BPIFrance.

[27] Leahey, C. (2011). Negotiating a Parallel Curriculum: Making Space for Critical Civic Literacy in the Social Studies Classroom. New York: Peter Lang.

[28] Lee, J., Lapira, E., Behrad, B., \& Hung-an, K. (2013). Recent advances and trends in predictive manufacturing systems in big data environment. Manufacturing Letters, 1, 38-41.

[29] Liffler, M., \& Tschiesner, A. (2013). The Internet of Things and the Future of Manufacturing. McKinsey: Company.

[30] Lowy, N. (2013). Learning styles, critical thinking aptitudes, and immersion learning in physician assistant students. Unpublished Doctoral Dissertation. Seton Hall University Dissertations and Theses (ETDs).

[31] McGonagle, T. (2011). Media literacy: No longer the shrinking violet of European audiovisual media regulation? In Media Law and Policy.

[32] Miller, T. W., Kraus, R., \& Veltkamp, L. J. (2005). Character education as a prevention strategy in school-related violence. Journal of Primary Prevention, 26, 455-466.

[33] Milner, H. (2002). Civic literacy: How informedcitizens make democracy work. HanoverNH: University Press of New England.

[34] Monroe, B. (2004). Crossing the Digital Age: Race, Writing, and Technology in the Classroom. New York: Teachers College Press.

[35] Mossberger, K., Tolbeert, C. J., \& McNeal, R. S. (2008). Digital Citizenship, The Internet, Society, and Participation,. Cambridge, Massaachusetts London, England: The MIT Press.

[36] Rubenfeld, M., \& Sceffer, B. (2015). Critical Thinking TACTICS for Nurses. Jones \& Bartlett, Boston, MA.

[37] Rui, M., Celina, T., \& Isabel, M. (2011). Critical thinking: Conceptual clarification and its importance in science education. Science Education International, 22, 43-45.

[38] Salpeter, J. (2008). 21st Century Skills: Will Our Students Be Prepared.

[39] Sung, T. ((2017). Industri 4.0: a Korea perspective. 
Technological Forecasting and Social Change Journal, l, 1-6.

[40] Teitelbaum, K. (2010). Critical Civic Literacy in Schools. In Adolescent Education: A Reader. New York: Peter Lang.

[41] Vygotsky, L. (1978). Mind in Society: The development of Higher Psychological Processes. Cambridge, MA: Harvard University Press.

[42] Was, C., Woltz, D., \& Drew, C. (2006). Evaluating character education programs and missing the target: A critique of existing research. Education Research Review, 1, 148-156.

[43] Weisz, J. R., Sandler, I. N., \& Durlak, J. A. (2005). Promoting and protecting youth mental health through evidence-based prevention and treatment. American Psychologist, 60, 628-648.

[44] Xu, e. (2016). A Study on the Effects of Teachers' Information Literacy on Information Technology Integrated Instruction and Teaching Effectiveness. Eurasia Journal of Mathematics, Science and Technology Education, 12, 335-346. 